Portland State University

PDXScholar

Spring 7-15-2019

\title{
An Examination of Non-waged Labor and Local Food Movement Growth in the Southern Appalachians
}

Amy Kathryn Marion

Portland State University

Follow this and additional works at: https://pdxscholar.library.pdx.edu/open_access_etds

Part of the Agricultural Education Commons

Let us know how access to this document benefits you.

\section{Recommended Citation}

Marion, Amy Kathryn, "An Examination of Non-waged Labor and Local Food Movement Growth in the Southern Appalachians" (2019). Dissertations and Theses. Paper 5036.

https://doi.org/10.15760/etd.6912

This Thesis is brought to you for free and open access. It has been accepted for inclusion in Dissertations and Theses by an authorized administrator of PDXScholar. Please contact us if we can make this document more accessible: pdxscholar@pdx.edu. 
An Examination of Non-waged Labor and Local Food Movement Growth in the Southern Appalachians

by

Amy Kathryn Marion

A thesis submitted in partial fulfillment of the requirements for the degree of

\author{
Master of Urban Studies \\ in \\ Urban Studies and Planning
}

Thesis Committee:

Megan Horst, Chair

Nathan McClintock

Daniel Jaffee

Portland State University

2019 


\begin{abstract}
Farmers have traditionally depended on their families or paid employees to cover their extensive labor needs. Today, non-waged labor models are gaining popularity, especially among small, ecologically-oriented farms. Apprenticeships and internships can be a primary form of training for a population of new and beginning farmers, many of whom are entering the field without farming backgrounds. However, many question the sustainability and justness of these arrangements. As a new phenomenon, very little research examines the relationship between non-waged labor models like agricultural apprenticeships and alternative food movements. In this exploratory study, I surveyed nearly 250 farmers growing for local markets in the Southern Appalachians to better understand their rationales for using waged or non-waged labor, and to explore how those decisions impact the local food movement developing within the region. I find that farmers using non-waged labor are smaller, less profitable, and more likely to be new to farming than their wage-paying counterparts, and that they choose to host non-waged laborers for both economic and noneconomic reasons. Ultimately, I find that non-waged labor models create incremental steps towards changing the food system by educating new farmers and food systems advocates, increasing the transparency of agricultural labor practices, and giving small-scale farmers a chance to grow their business and get more products into the local economy. However, the non-wage labor model may not be sustainable in the long run, and it perpetuates injustices, such as the exclusion of those who can't afford to train without pay, and it should evolve as the food system evolves.
\end{abstract}




\section{Acknowledgments}

Thank you first and foremost to my advisor, Dr. Megan Horst, for her guidance through all stages of this research. I am so appreciative of her and the rest of my committee, Dr. Nathan McClintock and Dr. Daniel Jaffee, for introducing me to the canon of critical food studies, and for their valuable feedback. I am also incredibly grateful to Dr. Allison Perrett for her edits on this work and for kindly permitting me to use ASAP resources along the way. I am equally thankful for all the farmers who took the time out of their busy lives to thoughtfully answer my survey questions. Finally, thank you to my cohort and friends for providing encouragement and distraction at all the right times, my family for pushing me to pursue higher education, and my husband, Colin, who has patiently listened to me reason through each step of this research project (and multiple iterations) over the last three years. This research wouldn't be complete today without all of your support. 


\section{Table of Contents}

Abstract........................................................................

Acknowledgements..........................................................

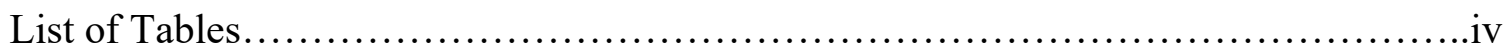

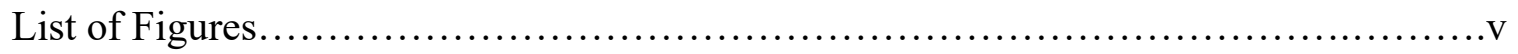

\section{Chapter 1}

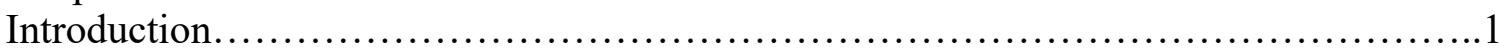

Chapter 2

Literature Review...........................................................

Chapter 3

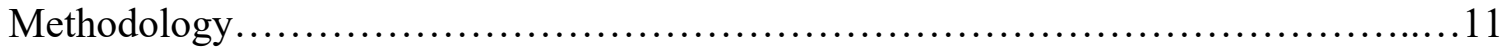

Chapter 4

Results.................................................................15

Chapter 5

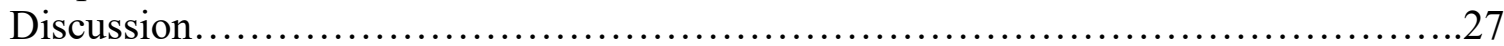

Chapter 6

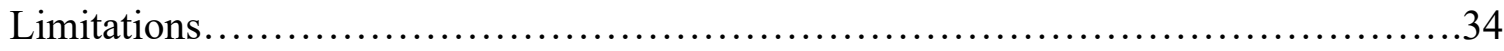

Chapter 7

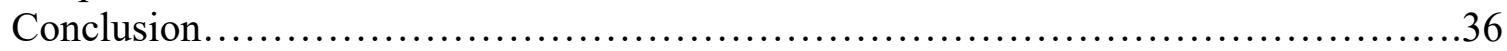

References...........................................................40 


\section{List of Tables}

Table 1: Appalachian Grown Farm Characteristics.................................16

Table 2: Farm Characteristics of All Farms in Appalachian Grown Region..............17

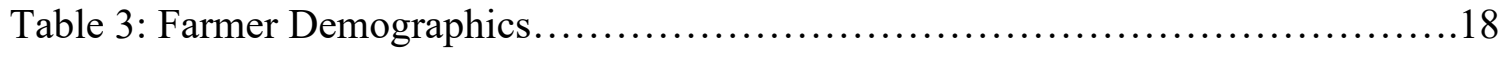

Table 4: Labor Models of Appalachian Grown Farms..............................18

Table 5: Farm Characteristics by Farm's Labor Model...............................21

Table 6: Changes in Appalachian Grown Farms Labor Models........................22 


\section{List of Figures}

Figure 1: Appalachian Grown Region.........................................9 


\section{Chapter 1}

\section{Introduction}

A primary concern for small-scale farmers is deciding on an appropriate labor model to support the scale and goals of their farm business. Many opt to limit their labor to their immediate family, but those who do rely on outside labor have two general choices, grouped broadly as: 1) waged labor, including migrant workers with temporary agricultural visas (H-2A), contracted labor crews, and hourly employees, and 2) nonwaged labor, including apprentices, interns, workers in the World Wide Opportunities on Organic Farms (WWOOF) program, and volunteers. As a fairly new phenomenon, nonwaged labor models are gaining popularity across the country, but they raise some concerns that researchers are just beginning to explore. In one of the key studies on this topic, Ekers et al. (2016) examine the significance that non-waged labor holds for small, ecologically-oriented farms by exploring the factors that have contributed to the rise of this practice. Ultimately, Ekers et al. (2016) question whether non-waged labor is just and sustainable for farmers and apprentices alike, and if it's a good practice upon which to build a sector or social movement. They suggest that more research is needed to understand the contradictions and challenges of this type of labor.

The following research aims to respond to and expand upon Ekers et al.'s (2016) questions through an examination of the labor practices used by farmers growing primarily for local markets in the Southern Appalachian region of the United States. Following a brief review of other research, I share a description of the Southern Appalachians and the local food movement that is developing there. I examine 
quantitative and qualitative data gathered from a survey of nearly 250 farmers in the region. I compare farms using different labor models by examining their farm sizes, gross incomes, dependence on off-farm incomes, sales to direct markets, and how long they've been farming. Finally, I explore the impact that the non-waged labor model may have on the local food movement growing in this region. 


\section{Chapter 2}

\section{Literature Review}

\section{Labor and the Agrarian Question}

Over the last century the farming industry has shifted dramatically from small to largescale farming. Capitalism's preferencing of profit over people and planet has led to the consolidation of small family farms, and the rise of corporately-owned and globallyoperated agribusinesses (Howard, 2016; Lyson, 2004). Following the general laws of capital accumulation, as these large conventional farms grew, they were able to increase productivity and decrease labor costs through technological advances and investments in machinery (Goodman, 1987; Marx, 1887). Most agribusinesses have maximized automation to minimize labor needs. For tasks that cannot efficiently be mechanized, agribusinesses hire the majority of their workers through the federal H-2A program, which provides seasonal visas for foreign workers to fill temporary agricultural jobs (Huennekens, 2018).

Despite predictions of the eventual demise of family-scale farms, they've persevered against their corporate competitors. A century-long speculation over the ability of small farms to persist is known as the "agrarian question." While many theories address the agrarian question, I build on Kautsky's (1988) position that farming presents significant barriers to capitalist penetration and that small-scale farmers' self-exploitation has allowed them to resist market competition. Ekers et al. (2016) suggest that farmers' use of non-waged labor on small-scale farms can be understood as a renegotiation of the agrarian question. Ekers (2019) explains that within this debate, the use of non-waged 
labor, can be understood both from a political economy perspective, and a populist perspective.

From a political economy perspective, the pressures of capitalism have resulted in low food prices and high land prices, pushing small-scale farmers to rely upon selfexploitation and unpaid labor in order to maintain their businesses (Ekers, 2019; Galt, 2013). Unlike large agribusinesses, small-scale farms are able to continue producing without receiving what the market would consider appropriate economic returns by undervaluing their labor and their family's labor (Galt, 2013). Labor is often the most expensive line item for small-scale farms operating with minimal profits. This is especially true for ecologically-oriented farms, which preference manual labor over chemical and mechanical inputs (Bruce and Castellano, 2016; Buck et al., 1997; Weiler et al., 2016). Historically, small-scale farms relied heavily on unpaid family labor. Today, smaller family sizes and children seeking employment off the farm has led to the replacement of those kinship relationships with apprenticeships (Ekers and Levkoe, 2016). Non-waged labor models thus allow small-scale farm businesses working in a capitalist market enough financial flexibility to sustain themselves year after year.

However, the practice can also be understood through a populist lens. Historically, farmers' self-exploitation has allowed them to fulfill their non-capitalist goals of participating in a moral economy, and other lifestyle benefits of their work such as autonomy and self-provisioning (Galt, 2013). Farms driven by non-economic values are seen as places of resistance to capitalist logic, and non-waged labor practices similarly 
allow farms the flexibility to participate in a moral economy and can also be used as a way to de-institutionalize and de-commodify agricultural education (Ekers, 2019). In their study, Ekers et al. (2016) show that small-scale, ecologically oriented Ontario farmers gave both economic and non-economic explanations for using non-waged labor. The non-economic values cited included building community, participating in a larger movement, and training the next generation of farmers. Today, few aspiring ecologically oriented farmers come from agricultural backgrounds, so they have distinct and extensive educational needs (MacAuley and Niewolny, 2016). Due to the immense amount of upfront capital required to start a farm and the challenging nature of the industry, aspiring farmers are encouraged to spend multiple years gaining hands-on experience before embarking on their own (DelCogliano, 2015; Levkoe, 2017). There are a range of newfarmer training models, from informal farm internship associations, to private or nonprofit programs, to formal academic programs (Schreiner et al. (2018). These training models are most popular on small-scale farms that are seen as alternatives to capitalist logic in that they exercise ecologically oriented growing practices, sell directly to their consumers, and place a lower value on profits.

\section{Agricultural Apprenticeships}

This research focuses primarily on the use of apprentices and interns organized by both informal farm internship associations, and non-profit programs. Like apprenticeships in other industries, these arrangements are organized as an exchange of labor for education, often supplemented by a modest monthly stipend ranging from $\$ 100-\$ 600$ per month. However, most agricultural apprenticeships offer additional non-monetary benefits like 
on-farm housing and surplus farm products. While some non-waged labor arrangements can be as short as a week or two, most agricultural apprenticeships run year-round or during the primary growing season from March to November. Beyond these general characteristics, agricultural apprenticeships are fairly unstructured. This is in contrast to other industries known for hands-on training, like electrical or plumbing apprenticeships, which are organized and backed by unions and generally lead to more secure job placements (Berik and Bilginsoy, 2000).

For aspiring farmers, apprenticeships are far less expensive than a four-year institutional degree, and for farmers they are much more affordable than waged laborers. However, they are often informal and unregulated, which can create a sense of precariousness for both parties. Ekers et al. (2016) found that non-waged laborers are less likely to be skilled and may not possess the work ethic of a paid worker. Additionally, both the farmer and apprentice lack the commitment guaranteed by a contract. Farmers can face losing crops and profits if an apprentice quits mid-season and apprentices have little guarantee about the quality of the training they will receive, which is ultimately up to the farmer's personality, resources, and commitment to education (Ekers et al., 2016; Weiler et al., 2016).

Agricultural apprentices may be forgoing other potentially waged labor, but they generally do not face the same level of risk as the farmer or more traditional agricultural laborers. Following the end of legal slavery, federal and state labor regulations have continued to exclude agricultural laborers from the protections created to maintain 
standards of living for other industrial workers. These include New Deal-era regulations like the Fair Labor Standards Act of 1938 and the National Labor Relations Act in the mid-1930s, which guaranteed a minimum wage, overtime pay, workers compensation and collective bargaining for non-agricultural workers (Getz et al., 2008; Rodman et al., 2016; Schell, 2002). Many scholars have exposed the abuses waged laborers face on large-scale, conventional and organic farms (Getz et al., 2008; Holmes, 2013; Shreck et al., 2006). Others have found that these abuses are not unique to large farms, but also occur on some small-scale ecologically-oriented farms selling direct to consumers (Gray, 2014; Berkey and Schusler, 2015). However, the few researchers who have studied the experiences of non-waged laborers have shown that most apprentices possess a certain amount of socioeconomic privilege that allows them to forgo a wage and the labor protections that others would need in order to participate (Guthman, 2017; MacAuley and Niewolny, 2016; Weiler et al,. 2016). MacAuley and Niewolny (2016) highlight how this limits people from low socioeconomic backgrounds from participating in apprenticeships, and farming in general, and contributes to concerns raised about alternative food movements' inadequacies in addressing social injustices in the food system (Allen, 2004; Guthman, 2014).

Given the agricultural industry's sordid history with enslaved and abused workers, and the precarity this labor model can create, Ekers et al. (2016) ask if the agricultural sector or alternative food movements can and should be built on the backs of unpaid labor. They call for more socially and spatially diverse investigations of non-waged labor to expand the research beyond Ontario, Canada. This research answers that call by exploring the use 
of non-waged labor arrangements on farms in the Southern Appalachian Mountains, and what impact they have on the local food movement growing there.

\section{Local Food Movement Growth in the Southern Appalachians}

The local food movement in the Southern Appalachian Mountains is a key opportunity for studying non-waged labor and alternative food movement development. In the last two decades, agriculture in the region experienced a dramatic shift. For nearly a century, this rural region's culture, landscape, and economic stability revolved around burley tobacco, a cash crop uniquely well-suited to the region's soil and supported by federal quotas through the late 1990s. In 2004, the Fair and Equitable Tobacco Reform Act, also known as the "tobacco buyout" ended all government protections for the crop (Jackson and Perrett, 2018). Funds from the 1998 Master Settlement Agreement, and the Tobacco Transition Payment Program, were directed to help transition rural, economically distressed communities through this change, but there were few market opportunities for farmers that would be as profitable as tobacco had been.

In 2000, a nonprofit called Appalachian Sustainable Agriculture Project (ASAP) formed a Local Food Campaign to build a market alternative for farmers to encourage and support a transition from tobacco to fruit and vegetable production. Their mission is to help local farms thrive, link farmers to markets and supporters, and build healthy communities through connections to local food. As ASAP began defining the boundaries of their work, they discovered that when compared with the surrounding Appalachian counties, they had less in common with the central and eastern part of North Carolina, 
where a majority of the population resides, and where the farms are larger and less impacted by the loss of tobacco. Today, ASAP serves nearly 900 farms within 100 miles of Asheville, North Carolina - home to approximately 92,000 people, and the largest metropolitan area in Western North Carolina. While much of the support is centered around Western North Carolina, the region's 60 counties include Upstate South Carolina, Northern Georgia, Eastern Tennessee, and Southwestern Virginia, as seen in Figure 1. With the support of this organization, Western North Carolina simultaneously experienced a $97 \%$ reduction in tobacco farms and a $98 \%$ increase in farms growing fruits and vegetables from 1997 to 2012 (Jackson and Perrett, 2018).

Figure 1: Appalachian Grown Region

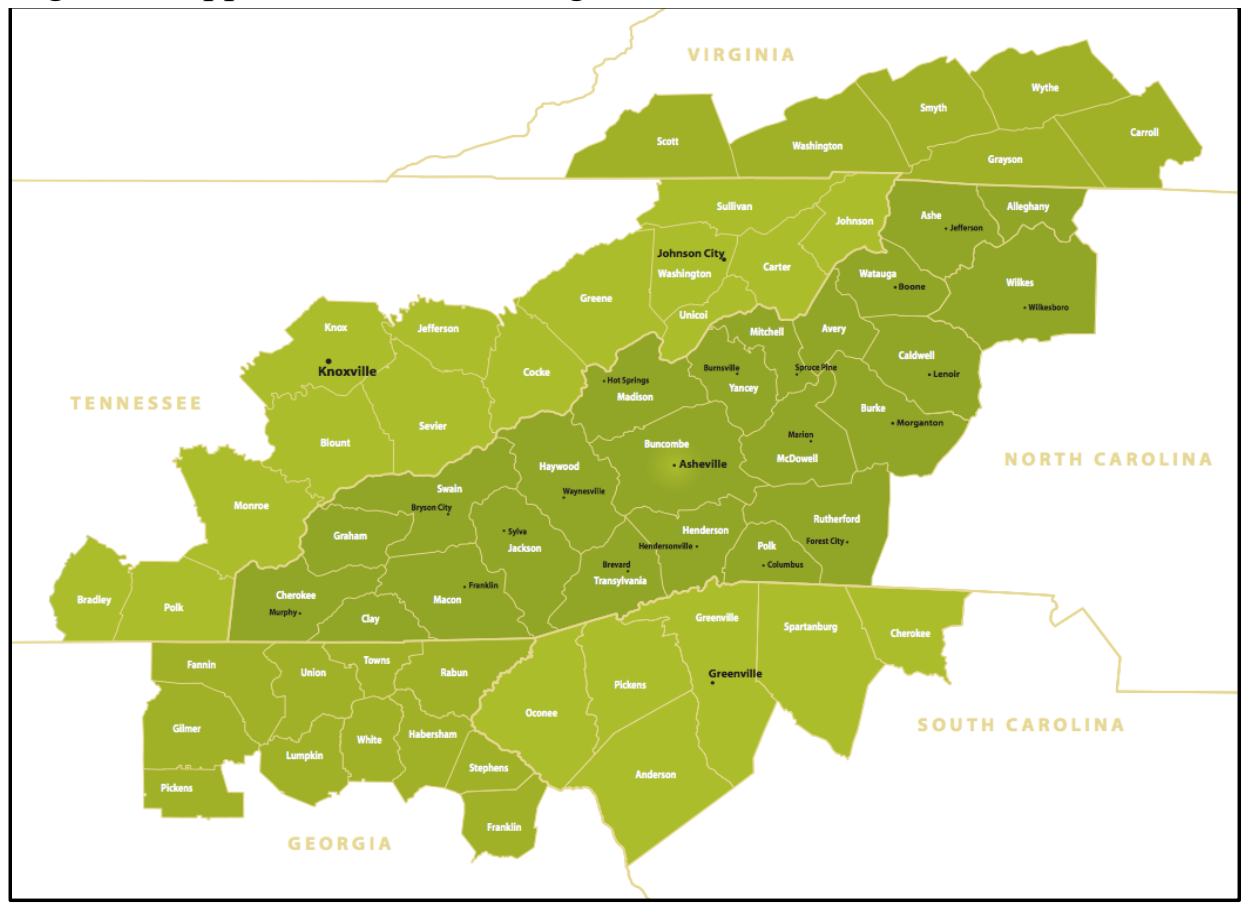

Note: Adapted with permission from Appalachian Sustainable Agriculture Project.

ASAP's Local Food Campaign has served as the basis for the region's social movement building around an alternative, localized food system. The campaign works to provide 
marketing support and training to farmers, build markets for local products, introduce the area's youth to agriculture, and connect producers and consumers. At its core, their philosophy suggests that by providing consumers with transparent, face to face experiences with local farms and the people growing their food, they will have a better understanding of the food system and a stronger connection and willingness to support local farmers and advocate for change. After nearly 20 years from ASAP's inception, the Appalachian Grown region of the Southern Appalachians is now home to a thriving local food system that includes 127 farmers markets, 104 CSA programs, 110 farms offering upick agritourism, and over 250 restaurants, bakeries, and caterers sourcing local products. Ultimately, the region's local food movement is an important economic driver for the community and model for other alternative food movements. 


\section{Chapter 3}

\section{Methodology}

In this study, I aim to improve the understanding of why some farmers in the Southern Appalachians use non-waged labor compared to other labor models, and the impact their choice has on the local food movement developing there. I achieve this through an online survey of Southern Appalachian farmers, and I add context with data from the 2017 Census of Agriculture and ASAP's Appalachian Grown farmer database.

There are approximately 37,000 farms in this region, but only 900 of them participate in a free local certification program administered by ASAP called Appalachian Grown. Based on their voluntary decisions to be certified, I can infer that Appalachian Grown farmers see value in marketing their products under local branding. Thus, by restricting this study to only these farmers, I anticipate their responses will best reflect the perspectives of those actively engaged in developing a local food movement within the area. However, they are not representative of all farms in the region. I use 2017 USDA Census of Agriculture data to compare the demographics and farm characteristics of Appalachian Grown farmers to all the farmers in the region.

Every year, ASAP surveys all Appalachian Grown farmers to learn about their farm businesses and their farming experiences over the previous year. In January 2018, I sent the electronic survey to 852 Appalachian Grown farmers who had a current email address in ASAP's database. The survey was open for three weeks and I sent a reminder once a week. A total of 239 surveys were completed, a 28\% response rate. Following an IRB- 
approved protocol, I included an additional set of questions about labor practices and labor-related challenges. These questions were prefaced with an explanation of this research project, the voluntary nature of their participation in it, and an assurance of the subject's anonymity.

The added set of survey items included both closed and open-ended questions to understand more about their farming businesses and labor practices. The closed questions asked about their farm characteristics such as their farm acreage, gross income, the percent of their household income that was derived from their farm business, what percent of their products were sold directly to consumers, and their amount of farming experience. Farm acreage data included land not under production and all grazing and rangeland. Gross income data and the percent of their household income generated from their farm were reported as ranges. I used the federal definition of New and Beginning farmers (farming for ten years or less) to understand how new they were to farming (USDA, 2010). Data on direct sales were captured as a percentage of all sales, and included sales at tailgate markets, on-farm stands, through agritourism ventures, CSAs, or direct to chefs.

Farmers then reported whether they hosted or employed non-family workers on their farm, including waged labor, non-waged labor, or both waged and non-waged labor. Waged labor was defined as including hourly employees, independent contractors, and H-2A workers. Non-waged labor was defined as including interns, apprentices, WWOOFers, CSA members, etc. The survey also explained that workers are considered 
non-waged even if they receive stipends or in-kind benefits such as education and/or room and board.

I then examined the quantitative survey responses in order to understand if farms using the four labor models are significantly different from each other. My data had neither equal variance, nor normality, so for the two farm characteristics with continuous data (acres and the percent of their products sold directly) I performed a Kruskal-Wallis rank sum test, as a non-parametric alternative to a one-way ANOVA test. I then performed the Dunn test as a post-hoc analysis. Gross farm income and the percent of household income generated from their farm business were both reported as ranges, so I analyzed them as categorical data, along with whether the farmer was a New and Beginning farmer, by performing Chi-square tests.

The open-ended questions asked farmers to explain their rationales for using their chosen labor model and related challenges. In order to analyze similarities and differences between farms using different labor models, I grouped their responses by their primary labor model and used open coding to draw out themes in their responses. For farmers using non-waged labor, I found their rationales fell under three themes, including financial limitations, commitment to education, or community building. For farmers using waged labor, the common themes for their rationales included doing so out of necessity, preferring those workers' characteristics, or doing so based on personal ethics. For farmers using only family labor the themes of their rationales included doing so because it fit their scale, financial limitations, or administrative barriers. Many of the 
respondents who selected 'both' explained that one was their primary labor type and the other was occasional labor. For example, some primarily hosted apprentices, but paid a farm manager hourly, or they employed contract labor for specific, one-time tasks like building a fence. Others explained they primarily used waged labor but taught a couple high school-aged neighbors about farming during the summer or had friends work a few days in exchange for produce. Due to these inconsistencies, I combined them with the group they aligned with most closely. 


\section{Chapter 4}

\section{Results}

I begin this section by describing the average Appalachian Grown farm and comparing it to the average farm in the region. I then share the labor models Appalachian Grown farmers reported using and analyze differences in their farm characteristics based on their primary labor model. I then explore and illustrate these differences by comparing farmers' motivations for using each labor model through a selection of quotes.

\section{Farm Characteristics of Appalachian Grown Farms}

In the Southern Appalachians, the geography, the legacy of Burley tobacco, and the impact of ASAP's Local Food Campaign are all reflected in the farm characteristic data gathered from the survey and shown in Table 1 . The mountainous terrain in this region limits viable farmland to valley bottoms, resulting in smaller farms and farmers operating on a patchwork of multiple land parcels. Appalachian Grown farms have an average size of only 46 acres, including grazing and rangeland. This average includes a few farms over 500 acres, which raises the average much higher than the median of 6 acres. More than half $(56 \%)$ of farmers have been farming for ten years or less. Their median gross income is $\$ 10,001-\$ 40,000$ and the median value for the percent of their household income derived from their farm business is $11-25 \%$. They sell an average of $75 \%$ of their products to direct markets. Ultimately, these data present a picture of farms that are small, run by fairly new farmers, selling primarily to direct markets, and making insufficient profit to sustain their farm businesses without off-farm income. 
Table 1: Appalachian Grown Farm Characteristics

\begin{tabular}{|c|c|c|c|c|}
\hline $\begin{array}{c}\text { Average } \\
\text { Acreage }\end{array}$ & $\begin{array}{c}\text { Farmed 10 Years } \\
\text { or Less (\%) }\end{array}$ & $\begin{array}{c}\text { Median Gross } \\
\text { Income (\$) }\end{array}$ & $\begin{array}{c}\text { Median Household } \\
\text { Income Generated (\%) }\end{array}$ & $\begin{array}{c}\text { Average Direct } \\
\text { Sales (\%) }\end{array}$ \\
\hline 46 & 56 & $10,001-40,000$ & $11-25$ & 76 \\
\hline
\end{tabular}

Appalachian Grown Farms Compared to All Farms

Appalachian Grown farms account for only $2.4 \%$ of the 36,869 farms in the 60 -county region of the Southern Appalachians. Not all data points can be compared directly, but data from the 2017 Census of Agriculture shows that on average Appalachian Grown farms are smaller and less profitable than all farms in the region. As seen in Table 2, the average farm acreage is twice as large as Appalachian Grown farms (98 acres). Only 25\% of all the farmers in the region have been farming for 10 years or less, compared to $56 \%$ of Appalachian Grown farmers. The average farm sales for all farms in the region is $\$ 92,000$ which more than double the median range of Appalachian Grown farms' gross income. Only about $8 \%$ of all farms in the region sell products directly to consumers, direct sales only account for $2 \%$ of all farm sales in the region, compared to $76 \%$ of Appalachian Grown farms sales. Finally, while the Census of Agriculture does not provide information on what percent of farmer's household income was generated by their farming business, $41 \%$ of principal operators in this region reported farming as their primary occupation, which gives some indication of the percent of farmers relying on offfarm incomes. 
Table 2: Farm Characteristics of All Farms in Appalachian Grown Region

\begin{tabular}{|c|c|c|c|c|}
\hline $\begin{array}{c}\text { Average } \\
\text { Acreage }\end{array}$ & $\begin{array}{c}\text { Farmed 10 Years } \\
\text { or Less (\%) }\end{array}$ & $\begin{array}{c}\text { Average Farm } \\
\text { Sales (\$) }\end{array}$ & $\begin{array}{c}\text { Farming as Primary } \\
\text { Occupation (\%) }\end{array}$ & $\begin{array}{c}\text { Average Direct } \\
\text { Sales (\%) }\end{array}$ \\
\hline 98 & 25 & 92,000 & $41 \%$ & 2 \\
\hline
\end{tabular}

Many of these differences can be accounted for by considering the types of farms in the region. Using the NAICs data provided by the 2017 Census of Agriculture, it's clear that most of the farms in this region are not producing high volumes of food. Only $7 \%$ of farms are classified as growing vegetables, fruits, and tree-nuts. An additional 17\% produce dairy products, hogs, aquaculture, poultry, and eggs. The largest percentage of farms $(46 \%)$ are those raising cows. In this mountainous region, these are not cattle feedlots, but generally low volume operations used as a way to retain a lower agricultural tax rate on expensive forest and pasture land (Kays, 2019). Farms growing hay rank second, accounting for $22 \%$ of all farms in the region. ASAP updates a database of this information annually for all Appalachian Grown farmers as part of their ongoing certification, and while these values can't be compared directly to ASAP's data it shows that Appalachian Grown farms primarily produce food, and generally a diversified mix. This includes 50\% of Appalachian Grown farms growing vegetables, 39\% growing fruit, $5 \%$ growing nuts and seeds, $26 \%$ producing dairy and eggs, $24 \%$ producing meat and fish, and $32 \%$ growing flowers.

The Census of Agriculture also reports on the demographic make-up of farm operators. While my survey did not include these questions, I used Census data and ASAP data to further compare Appalachian Grown farmers to all farmers in the region (Table 3). 
Overall, Appalachian Grown farmers are slightly younger and more diverse, although $92 \%$ are white and $61 \%$ are men.

Table 3: Farmer Demographics

\begin{tabular}{|c|c|c|c|c|}
\hline & White (\%) & People of Color (\%) & Female (\%) & Average Age \\
\hline $\begin{array}{c}\text { All Principal } \\
\text { Producers }\end{array}$ & 98 & 2 & 28 & 59 \\
\hline $\begin{array}{c}\text { Appalachian } \\
\text { Grown Principal } \\
\text { Producers }\end{array}$ & 92 & 8 & 39 & 51 \\
\hline
\end{tabular}

\section{Labor Models of Appalachian Grown Farmers}

Table 4 shows that nearly half (49\%) of the Appalachian Grown survey respondents reported using solely family labor on their farm. For those farmers that do rely on outside labor, 30\% reported using only waged labor, $10 \%$ reported using only non-waged laborers, and $10 \%$ reported using both waged and non-waged workers.

Table 4: Labor Models of Appalachian Grown Farms

\begin{tabular}{|l|c|c|}
\hline Labor Models & N & Percent \\
\hline Family Labor Only & 103 & 49 \\
\hline Non-waged Labor & 22 & 10 \\
\hline Waged Labor & 63 & 30 \\
\hline Non-Waged and Waged Labor & 22 & 10 \\
\hline
\end{tabular}

\section{Differences in Farm Characteristics by Labor Type}

When farm characteristics are analyzed by labor type, distinct differences are apparent, as seen in Table 5. A Kruskal-Wallis test confirmed there was significant difference 
between the average acreage of farms using different labor types. A Dunn test showed that the average farm size for farms using only family labor (30 acres) and only nonwaged labor (14 acres), are significantly smaller than farms using waged labor (92 acres), with p-values of 0.002 and 0.04 respectively. Farms using both waged and non-waged labor have an average farm size of 42 acres, which is closest to the overall average of 46 acres and is not statistically different from the farms with other labor models.

A Kruskal-Wallis test confirmed there was also significant difference between farms' labor models and the percent of the products they sold directly to consumers. Farms using waged labor sell an average of $60 \%$ of their products directly to consumers, making them the least likely to do so. Farmers using only family labor, only non-waged labor, or both waged and non-waged labor are slightly more likely to sell their products to direct markets at $81 \%, 82 \%$, and $83 \%$ respectively. However, a Dunn test showed that percent of products sold directly are only significantly different between farms using waged labor and those using only family labor $(\mathrm{p}=0.0004)$.

Gross farm income shows the greatest level of variation between farms with different labor types. The median gross income for farms using only family labor and farms using only non-waged labor was 'less than $\$ 10,000$.' Despite both groups falling into the same range, only $35 \%$ of those with only family labor reported grossing more than $\$ 10,000$, compared to $45 \%$ of those with non-waged labor. Neither group reported incomes over $\$ 200,000$. Farms using only waged labor reported a median gross income of $\$ 40,001$ $\$ 80,000$, including $22 \%$ of which that reported grossing over $\$ 200,000$. Farms using both 
waged and non-waged labor reported a median of $\$ 10,001-\$ 40,000,10 \%$ of which grossed over $\$ 200,000$. A Chi-square test showed that the relationship between all labor types were statistically significant from each other at a 0.05 level except for the relationship between farms using waged labor to farms using both waged and non-waged labor.

Farms using exclusively waged or non-waged labor are most similar to each other in terms of the percent of their household income that is generated from their farming business. Both groups earned $26-50 \%$ of their household incomes on the farm, which is higher than the average of $11-25 \%$, but not as high as the $51-75 \%$ reported by those using a combination of waged and non-waged labor. In comparison, those using only family labor earned only $1-10 \%$ of their household income from their farm businesses. A Chisquare test confirmed that the percent of household income earned by farms using only family labor is significantly different than those using waged labor $(\mathrm{p}=0.001)$ and those using both waged and non-waged labor $(\mathrm{p}=0.0008)$.

Just over half (56\%) of all Appalachian Grown farmers are new to farming, i.e., farming for ten years or less. However, a greater percent of farmers using only family labor (62\%) and those using only non-waged labor (68\%) are new to farming. Conversely, only $40 \%$ of farmers using exclusively waged labor, and only $36 \%$ of farms using both waged and non-waged labor are new to farming. A Chi-square test shows that the percent of new farmers on farms using both waged and non-waged labor is significantly different than those using solely family labor $(\mathrm{p}=0.02)$ and those using only non-waged labor $(\mathrm{p}=$ 
0.03). Additionally, the percent of new farmers on farms using waged labor is significantly different than those using solely family labor $(\mathrm{p}=0.004)$ and those using only non-waged labor $(\mathrm{p}=0.001)$.

Table 5: Farm Characteristics by Farm's Labor Model

\begin{tabular}{|l|c|c|c|c|}
\hline & Family Labor & $\begin{array}{c}\text { Non-waged } \\
\text { Labor }\end{array}$ & Waged Labor & $\begin{array}{c}\text { Both Waged and } \\
\text { Non-waged Labor }\end{array}$ \\
\cline { 2 - 5 } & $\mathrm{N}=103$ & $\mathrm{~N}=22$ & $\mathrm{~N}=63$ & $\mathrm{~N}=22$ \\
\hline Acreage & 30 & 14 & 92 & 42 \\
\hline Direct Sales (\%) & 81 & 82 & 60 & 83 \\
\hline $\begin{array}{l}\text { Gross Income from } \\
\text { Farm Business (\$) }\end{array}$ & $\begin{array}{c}\text { Less than } \\
10,000\end{array}$ & $\begin{array}{c}\text { Less than } \\
10,000\end{array}$ & $40,001-80,000$ & $10,001-40,000$ \\
\hline $\begin{array}{l}\text { Household Income } \\
\text { Generated (\%) }\end{array}$ & $1-10$ & $26-50$ & $26-50$ & $51-75$ \\
\hline $\begin{array}{l}\text { Farmed 10 years or } \\
\text { less (\%) }\end{array}$ & 62 & 68 & 40 & 36 \\
\hline
\end{tabular}

\section{Changes in Appalachian Grown Labor Models Over Time}

Finally, Table 6 shows how farmers' labor models have changed over the last 10 years. The majority, 67\%, reported they had not changed their labor model. A handful of farmers reported that they previously had no outside labor and added waged labor (10\%) or non-waged labor $(6 \%)$. A few reported changing from non-waged labor to waged labor (3\%), and even fewer reported changing from waged to non-waged. Those that added labor to their farms explained that the change was related to scaling up, but the farmers shifting between waged and non-waged labor models offered few comments and therefore little insight into these changes. 
Table 6: Changes in Appalachian Grown Farms Labor Models

\begin{tabular}{|l|c|}
\hline Labor Model Changes & Percent \\
\hline From no outside labor to primarily waged labor & 6 \\
\hline From no outside labor to primarily non-waged labor & 3 \\
\hline From primarily non-waged labor to primarily waged labor & 2 \\
\hline From primarily waged labor to primarily non-waged labor & 67 \\
\hline I have not changed my labor model & 12 \\
\hline Other & \\
\hline
\end{tabular}

The survey concluded by asking farmers to explain the primary reasons behind their choice of labor model. The following section analyzes these rationales by labor type, starting with non-waged labor.

\section{Non-waged labor}

For the $10 \%$ of farmers who use a solely non-waged labor model, I coded their responses as either based in economic or non-economic reasoning to see how they compared to the research completed by Ekers et al. (2016). There was an even split between the two, including some who reported both reasons, confirming Ekers et al.'s assertion of a comingling of both; farmers are not simply hosting apprentices for their free labor. The economic reasons given were simple - they couldn’t afford to pay workers. However, a few reflected on their intention to pay more as their farm business grew, diversified, and became more profitable. One farmer shared, "We would like to be able to pay our workers much more. We need to increase the price of products or further refine our farm to be able to pay our apprentices more. This is something we set as a goal every year. As 
we have paid our workers more, we have had to supplement our own income in other ways since more of the farm income goes to them. Now we both do consulting, and we have rental houses, plus agritourism ventures."

The top two non-economic reasons farmers gave for using non-waged labors were related to education and/or community building. Some farmers perceived hosting non-waged labor as an opportunity to share their knowledge with a new generation of farmers. One farmer explained, "Coming from a non-farm background, I entered farming through completing apprenticeships myself. Without that onramp for us, I would have never been exposed to small scale farming." Another shared they use non-waged labor as a way to "create a culture of education and sharing of information, promoting sustainable farming as a viable alternative to conventional methods." Other farmers viewed hosting nonwaged laborers as an opportunity to build deeper connections with others and build community. One farmer said hosting apprentices is a "great way to engage in deeper relationships than simply employee-employer." Another explained they were, "trying to develop an anarchist community of people living from the land."

Many farmers shared that while they don't offer formal apprenticeships, they welcome occasional volunteers on their farm and see value in that as both a way to educate and engage their community. As one farmer expressed, "I love having CSA members here to participate. I love getting to know them and giving them a chance to experience something they and their children would not otherwise experience." Another shared, "I had two workers this past summer from inner-city Philadelphia because I wanted to give them an experience of life on a rural farm. They were with us for two weeks, worked on 
the farm, helped at the markets, and came away with an experience they would never have had in the city. Our market customers interacted with them and asked about them for weeks after they left. It was very satisfying." Others shared that their non-waged work force consisted of a strong network of friends and neighbors who will help with a big harvest in exchange for some of the bounty.

For many, the economic and noneconomic reasons are intertwined. As this farmer explains, apprenticeships are a win-win relationship and potentially the only way to get by within the current food system.

There are very few farms that can afford to pay hourly workers full time due to scale. Even those that do barely pay themselves a living wage. I do think we need to be able to pay more but we also are operating in a food system that doesn't value or pay well for our products. The apprentice model really does train folks to be farmers. By living and working so intimately at the farm they really understand how it all works and if they want to try it on their own. It is very different than wage workers who aren't as invested nor interested in the whole farm picture.

Some simply see non-waged labor as the only available option for their farm, despite associated challenges of time or inefficiency. As one farmer explains, "In [my] county, it is near impossible to find consistent/quality waged workers. Using alternative sources seems to work, though for me, it is a huge time commitment." Two farmers highlighted that non-waged labor works for them now, but perhaps not forever. One shared, "We are tweeners with our produce, too large for just my husband and myself, not large enough to hire out labor. We have the opportunity to grow, but not sure at this time if that is the direction we plan to go." The other explained, "Hiring farm help is difficult when we're 
not paying ourselves a whole lot in the first place. Attaining scale that would allow us to hire full-time help is difficult, but we'd rather have employees than interns."

\section{Waged labor}

When asked their primary reason for using waged workers, the majority of responses were simply related to necessity; they were operating at a large enough scale that they couldn't do all the work themselves and they didn't see another viable alternative. One farmer reasoned, "no one will pick blueberries for free.” Another questioned outright, "who will work for free?"

The second most frequently cited reason for hiring waged workers referenced those workers' character. Farmers explained they wanted to hire reliable people with knowledge, experience, and that would return year after year. One farmer explained, "we hire independent contractors to harvest and plant. They specialize in the crops we grow, which makes them efficient and experienced." One farmer shares their aversion to training farmers: "Interns want to be trained AND paid. Not an option for us. If I am going to pay \$10-\$15 an hour I don't want to have to teach them the job." Another highlights the benefit of consistency, "we've found it worth having ongoing waged workers rather than a rotation of non-waged workers." One farmer feels that reliability is directly related to pay, "By paying employees a living wage, I can depend on them to be more reliable as laborers." Another farmer explained, "one person cannot operate a farm. If that were possible, considering my experience, I would go out of my way not to have to rely on anyone." 
Ultimately though, some farmers do see their preference to pay a wage as an ethical choice. One farmer explains, "We prefer to use paid labor so I don't feel bad asking them to do what needs to be done." Another explains, "principle: fair and legal (how do you call yourself a "Sustainable" farm if it's on the backs of free labor?)"

\section{No outside labor}

For those farmers that relied solely on their own labor, $40 \%$ explained doing so because the scale of their farm was too small to support labor; waged or not. However, some suggest that may change in the future. One shared, "We are intentionally staying small scale to prevent the need for extra labor and will only scale up when we can pay an additional employee a living wage." Another 30\% explained they did not have the financial resources to pay workers. One farmer shared, "I don't make enough farm profit to pay anyone to do anything, including me and the wife half the time...It's a labor of love and building family/community resilience." The final $30 \%$ cited administrative and management challenges such as the time-consuming nature of finding and managing workers and the associated paperwork. One farmer explained, "We lost our excellent worker in 2016. Don't really want to take the time or energy and invest in someone else. We downsized." Another shared, "For two employees you have to hire an accountant just to keep up paperwork. I'll stay small.” 


\section{Chapter 5}

\section{Discussion}

With this research, I sought to better understand the rationales, challenges, and possibilities of using non-waged agricultural labor in the Southern Appalachians by comparing farms who use it to farms using other labor models. Using the above quantitative and qualitative survey results, the following section explores how just and sustainable the non-waged labor model is and the impact it may have on developing local food movements.

Is it just?

Given the contentious history of agricultural labor, a labor model that essentially provides farmers with free labor deserves critical examination. However, my survey data shows that Appalachian Grown farmers are not gaining excessive profits off their non-waged laborers. Only $10 \%$ of Appalachian Grown farmers use non-waged labor, and those that do operate farms that are half as big, and less profitable than the average Appalachian Grown farm. In contrast, farms using exclusively waged labor are twice as big and more than twice as profitable as the average. Over half the farms using non-waged labor are grossing less than $\$ 10,000$, which leaves little room to pay an employee, let alone cover all the inputs required to continue farming year after year. However, compared to farms with no outside labor, farms with non-waged labor report higher gross incomes, and more of their household income comes from their farm business. This may indicate that the use of apprentices offers farmers an opportunity to scale their farm business to a level of profitability that is reproducible year after year. 
While there is a critique that using "free" labor is unjust, it does not take into account all the resources that go into apprentices, nor does it compare the average apprentice to the average waged worker. Farmers often invest considerable time and resources into their apprentices and do not expect much capital gain in return. Free education is the obvious benefit of apprenticing, but in addition, most farms provide housing, utilities, a stipend, and farm products. Additionally, with apprenticeships, there is an expectation of upward mobility for aspiring farmers and so they are taught the diversified skills needed to run the whole farm business. This is generally not the case for waged workers who are often taught fewer aspects of farming and generally perform more repetitive tasks on a larger, less diversified scale. While some farms may opt to pay their waged workers above minimum wage and provide labor protections not required by law, most are likely following a legal code that systematically takes advantage of a vulnerable population in exchange for capital gain.

Another factor in preventing non-waged labor relationships from being exploitative is that within a strong local food movement there is a higher level of transparency and stronger personal relationships. When farmers sell their products through direct markets, the face to face interaction allows customers to ask questions about how it was grown. Customers frequently ask about farmer's ecological growing practices in order to inform their decision to purchase from farms who grow using standards that meet their personal values (organic, free range, etc). Similarly, this face to face interaction also allows customers to learn more about farms labor practices so they can choose to purchase from farms whose labor practices are non-exploitative. Those conversations are easier to start 
when labor models are more outwardly visible, like when farmers send their apprentices to manage their farmers market table and run deliveries to restaurants and CSA drop offs. Additionally, farmers selling through direct markets are beginning to rely heavily on social media for marketing and building their farm brand. Blog posts and pictures of their farm laborers offers another way to increase transparency and start conversations about how their products are being grown.

While this research did not survey apprentices or focus on the apprentice experience, others have found that apprentices generally do not feel exploited (Ekers, 2019). A major factor in this relates to their socioeconomic privilege, as apprentices are predominately white, upper-middle class, college educated women (Ekers, 2019; Guthman, 2017; MacAuley and Niewolny, 2016). As a primary form of new farmer training, this is yet another major barrier to people with lower socioeconomic status and communities of color, who have endured a long history of exploitation and exclusion from farming. Additionally, given the high price of land and the large amount of upfront capital required to start farming, working for free further limits aspiring farmers. Under this structure, only apprentices with substantial financial reserves or familial support are likely to succeed. While it may not be an exploitative practice, it is unfortunately an inaccessible one for many.

Is it economically sustainable?

Managing non-waged employees takes time and work, which may be why larger farms with higher gross incomes opt out of teaching apprentices and prefer to pay a wage. 
Many of the characteristics of non-waged labor that Ekers et al. (2016) described as contributing to a precariousness for both farmers and apprentices were not mentioned by farmers using non-waged labor, but were shared extensively by those using waged labor as a reason not to depend on unpaid workers. These include the lack of training, inefficiency, unreliability, and the challenge of having to find new apprentices every year. While farmers using non-waged labor surely feel these challenges, it may be that the economic and non-economic benefits outweigh them. Thus, the question of sustainability may depend on the farmer's primary intentions - whether they aim to maximize profits, or simply sustain their farm business and participate in a moral economy.

As Ekers (2019) explains, some small-scale farmers view themselves as farm businesses operating within a capitalist market. If the primary goal of these farm businesses is financial gain, then the precariousness of the apprentice-model likely won't be sustainable in the long run. It may however provide a necessary (but perhaps temporary) step up from running a business with no outside labor. The farm characteristics data showed that $62 \%$ of farms with no outside labor and $68 \%$ of farms with non-waged labor are new and beginning farmers, yet that number drops to $40 \%$ for farms with waged labor. This may indicate that new farmers use non-waged labor temporarily as they learn and slowly grow their farm business, but ultimately decide to pay waged laborers once they can afford to - a theme that also appeared in the quotes. 
Alternatively, some small-scale farmers place higher value on non-economic motivations for farming and are less concerned with market pressures, or see themselves as operating outside of the capitalist market. For these farmers, the use of non-waged labor may be less about having workers they couldn't otherwise afford, and more about training other aspiring farmers or local food advocates and engaging with the community around local food. They may also view apprenticeships as a non-institutional form of education which are therefore more aligned with principles of an alternative food movement.

There is of course a middle ground between these two in which farmers have chosen to farm expecting little economic gain, but acknowledging they still operate in a capitalist market and need to maintain a level of profitability that allows them to remain viable year after year. For these farmers, there may be a stronger comingling of economic and noneconomic reasons for using non-waged labor as well as an acknowledgement that as their profits increase, so should the compensation they give their apprentices. This was apparent in the number of quotes that expressed an intention and willingness to pay a living wage or otherwise improve their apprentices' situations along with their own.

\section{What impact does it have on local food movement growth in the Southern Appalachians?}

The results of this study have found that while non-waged labor is not an entirely just and sustainable labor model for farmers in the Southern Appalachians, it is not outright exploitative, and it provides some basic stepping stones that contribute to changing the conditions of the local food system. First and foremost, it provides an outlet for more people to be intimately involved with small-scale farms, whether they are on their way to 
becoming farmers themselves or want to deepen their relationship to food and farming. As a labor model that is more visible than migrant labor, it creates an opening for conversations about farm labor more broadly, and allows purchasers of local food to support farms that use labor practices that align with their values.

For farmers, non-waged labor is a way for them to teach, but also to grow their business and profitability. It provides a launch pad for them to scale up from using only family labor. While it takes considerable effort to find, train and manage apprentices each year, it allows farms to produce more, sell to more market outlets, and theoretically increase profits. Whether farmers decide to use that profit to scale up and pay waged workers that require less oversight, or use that profit to better their apprentices compensation likely depends on the values and business goals of the farms themselves.

Ultimately, building a more just and sustainable food systems requires time, and depends on incremental changes that create conditions for further changes. Paying workers a living wage and mentoring them would be a best case scenario that could lead to a wave of new farmers, from diverse backgrounds, gaining both the education and capital to begin farming. However, this is not possible when the average Appalachian Grown farmer in this region grosses $\$ 10,000-\$ 40,000$ and depends on off-farm work for the majority of their household income. Changing the structure of the food system depends on strengthening regional food economies by creating markets and demand for local food, which would lead to more people advocating for change at a state, national, and global level. However, just and transparent labor practices are an essential part of a 
successful alternative food system, so this model should continue to be monitored and refined. 


\section{Chapter 6}

\section{Limitations}

This research provides empirical data describing the labor practices of farmers in the Southern Appalachians, but is not without limitations, the first being my own possible bias. I approached this topic with eight months of first-hand experience apprenticing on a farm in this region in 2014. In addition, I am currently working as a researcher for Appalachian Sustainable Agriculture Project, a non-profit whose mission and programs seek to advance the local food movement within the Southern Appalachians. These experiences have the potential to bias my work, but arguably also provide unique insight into two sides of the non-waged labor debate. My own apprenticeship gave me a humble appreciation for the intensity of laboring on a small-scale farm, and the challenges and economic uncertainty these farmers face. While I had no intentions of farming long-term, the experience turned me into a lifelong advocate for local food and farms. In addition, I've witnessed the success of apprenticeships as a form of new farmer training. Two of my fellow apprentices have since started their own full-time farming businesses with the training they received. My position as a researcher for ASAP also informs my research. In this capacity, I am actively working to support farmers and advance local food movement goals, albeit often indirectly. Additionally, my research is unquestionably better due to my access to ASAP's database, and my ability to add questions to an annual survey that already has considerable buy-in from farmers.

Nearly 250 farmers responded to my survey, a 28\% response rate, which is fairly robust for an online survey. However, this still leaves room for considerable survey error, 
especially given only 10\% (22 farmers) reported hosting non-waged laborers. Based on an online database of farms posting apprenticeships, I believe it's fairly accurate that only $10 \%$ of Appalachian Grown farmers host non-waged labor. However, this small sample size could limit the accuracy of the assessments I made about farms hosting non-waged labor as a whole. Additionally, questions about labor can be both emotionally and legally complicated, so it could be that some farmers were less forthcoming with information about their labor models.

Finally, while this research confirms many of the same themes that Ekers et al., (2016) found in Ontario, Canada, it is not generalizable to all farming communities using nonwaged labor. Appalachian Grown farms are not representative of all farms in the region, let alone farms across the country. They are much smaller, primarily sell to direct markets, and many ascribe to a lifestyle of voluntary simplicity. Additionally, the local food movement has been building in the Southern Appalachians since the early 2000s and boasts a high level of transparency and personal relationships between local producers and consumers. This may not be the case elsewhere, where it could be easier to take advantage of labor that is less visible to the general public. 


\section{Chapter 7}

\section{Conclusion}

Non-waged forms of agricultural labor, including apprenticeships, are gaining popularity across North America as a form of new farmer training, and as a way for small-scale farmers to meet their extensive labor needs. As this practice takes hold, it is important to examine the effects it has on both parties involved as well as any social movements working to change the food system these farms are a part of. Recent research in Canada questioned the sustainability and justness of agricultural apprenticeships and called for more research to examine this phenomenon in order to deepen our understanding of it and the contradictions it presents. This research expands this non-waged labor scholarship to a region in the Southern Appalachian Mountains that has an especially strong local food movement. I examined what types of labor farmers were using and why, compared differences in the characteristics of farms using different labor models, and explored what impact non-waged labor has on the local food movement developing there.

I found that while farmers in this region are participating in building a local food system, they are still operating within the pressures of a global system that make it challenging to operate a financially viable farm business. These pressures push farmers in multiple directions to make a living. Most supplement their incomes with off-farm work and diversify their sales through direct markets. Fifty percent of them can't afford labor outside their own family members, and another ten percent use non-waged labor. However, economic gain is often not the only goal for these farmers. Those using nonwaged labor shared that they valued the opportunity to train aspiring farmers and engage 
with their community on a deeper level. Many self-reflexively acknowledged the shortcomings of the apprentice system. They expressed desires or intentions to compensate their apprentices better, but felt trapped by their financial circumstances, highlighting the challenge of holding petty commodity producers accountable for creating just labor arrangements when they too are in an economically precarious position. However, it remains to be seen whether non-waged labor arrangements will proliferate or if they are merely a temporary step for farmers as they grow their businesses. If the latter, the focus will be on the ability of these farms to maintain a role as changemakers in the food system.

Ultimately, the non-waged labor model will neither be the solution to or the downfall of successful alternative food movements. For apprentices, the model should continue to be monitored, and practitioners should look for way to make apprenticeships more accessible and fulfilling. For farmers, the model should be approached like many aspects of farming; as a risk. However, they should be well-practiced in identifying and determining whether the risk will be worth the reward - it may change from year to year. Overall, non-waged labor should be understood as a method that provides incremental steps towards changing the food system. It trains new farmers and educates food systems advocates, it increases the transparency of agricultural labor practices and generates conversations about a topic that has been infrequently discussed, and it gives farmers who couldn't otherwise afford outside labor a chance to grow their business and get more local products into the economy. 
There are many ways for future researchers to deepen and expand upon this study. While a number of open-ended survey questions invited comments, semi-structured interviews with Appalachian Grown farmers would tell a more complete story of their relationship with the non-waged labor model and how it can provide a means to scale farm businesses. The survey data on changes to farmers' labor models over time was limited and provided few insights, so interviews would also allow a better understanding of whether farmers move through non-waged labor on their way to waged, or if they plan to host apprentices indefinitely. Additional questions on the motives respondents have for their farms would also provide greater insight into the trade-offs they make regarding their labor decisions. Similarly, interviewing apprentices would extend insight into both sides of the non-waged labor model debate. They could provide a clearer description of any exploitation they feel as unpaid workers, as well as how this arrangement improves or hinders their future farming aspirations.

Although my survey did not collect demographic data, the farmers in this region are overwhelmingly white. This research did not explore the history of oppression related to agriculture in the American South and the impact that has on who farms in this region today. Briefly, this includes the ownership of land stolen from native communities, the wealth made off slave labor, and the structural discrimination that continues to benefit whites today (Horst and Marion, 2018). Future research should examine the demographics of both farmers and non-waged laborers to better understand how race and structural racism impact the use of non-waged labor and local food movement growth. 
Finally, this research focused on the labor models of a small group of farmers in a region where there is already a strong local food movement. Exploring the use of non-waged labor in other parts of the country could uncover regional differences, or expand upon questions raised by this work. The more that is learned about this labor model, the more we can do to improve it as a tool for changing the food system. 


\section{References}

Allen, P. (2004). Together at the Table: Sustainability and sustenance in the American agrifood system. University Park, PA: Pennsylvania State University Press.

Berkey, B., \& Schusler, T. (2016). Justice issues facing family-scale farmers and their laborers in the Northeastern United States. Journal of Agriculture, Food Systems, and Community Development, 6(2), 243-267.

Berik G. \& Bilginsoy C. (2000). Do unions help or hinder women in training? Apprenticeship programs in the United States. Industrial Relations: A Journal of Economy and Society. 39(4). 600-624.

Bruce, A. B., \& Som Castellano, R. L. (2016). Labor and alternative food networks: challenges for farmers and consumers. Renewable Agriculture and Food Systems, (December), 1-14.

Buck, D., C. Getz, and J. Guthman. (1997). From Farm to Table: The Organic Vegetable Commodity Chain of Northern California. Sociologia Ruralis, 37 (1): 3-20.

Delcogliano, N. (2015) Barriers to Farming in Western North Carolina. Retrieved from Organic Growers School website. http://organicgrowersschool.org/wpcontent/uploads/2015/08/ farmer_survey_report_final.pdf.

Ekers, M., Levkoe, C. Z., Walker, S., \& Dale, B. (2016). Will work for food: agricultural interns, apprentices, volunteers, and the agrarian question. Agriculture and Human Values, 33, 705-720.

Ekers, M., \& Levkoe, C. Z. (2016). Transformations in agricultural non-waged work: From kinship to intern and volunteer labor. Journal of Agriculture, Food Systems, and Community Development, 6(2), 179-183.

Ekers, M. (2019). The curious case of ecological farm interns: on the populism and political economy of agro-ecological farm work and political economy of agroecological farm work. The Journal of Peasant Studies, 46(1), 20-43.

Galt, R. (2013) The moral economy is a double-edged sword: explaining farmers' earnings and self-exploitation in community supported agriculture. Economic Geography, 89(4), 341-365.

Getz, C., Brown, S., \& Shreck, A. (2008). Class Politics and Agricultural Exceptionalism in California's Organic Agriculture Movement. Politics and Society, 36(4), 478507. 
Gray, M. (2014). Labor and the Locavore: The making of a comprehensive food ethic. Berkeley, CA: University of California Press.

Goodman, D., B. Sorj, and J. Wilkinson. (1987). From Farming to Biotechnology. Oxford: Basil Blackwell.

Guthman, J. (2014). Agrarian Dreams: The paradox of organic farming in California. Oakland, CA: University of California Press.

Guthman, J. (2017). Willing (White) Workers on Organic Farms? Reflections on Volunteer Farm Labor and the Politics of Precarity. Gastronomica: The Journal of Critical Food Studies, 17(1), 15-19.

Holmes, S. (2013) Fresh Fruit, Broken Bodies: Migrant farmworkers in the United States. Berkeley, CA: University of California Press.

Horst, M. and Marion, A. (2018). Racial, ethnic and gender inequities in farmland ownership and farming in the U.S. Agriculture and Human Values. 36(1)

Howard, P. H. (2016). Concentration and Power in the Food System: Who controls what we eat? New York, NY: Bloomsbury Academic.

Huennekens, P. (2018, August 6). Unlimited Cheap Farm Labor: Evaluating H-2A Disclosure Data. Retrieved from http://www.cis.org.

Jackson, Charlie and Allison Perrett. (2018). The End of Tobacco and the Rise of Local Food in Western North Carolina. Local Food Research Center, Appalachian Sustainable Agriculture Project.

Kautsky, K. (1998). The Agrarian Question. London: Zwan.

Kays, H. (2019). Effort like they've never had to give: Farmers get older and fewer, but hope remains for ages future. Smoky Mountain News. https://www.smokymountainnews.com/news/item/26352-effort-like-they-ve-neverhad-to-give-farmers-get-older-and-fewer-but-hope-remains-for-ag-s-future.

Levkoe, C. Z. (2017). Engaging the tensions of ecological internships : Considerations for agroecology and sustainable food systems movements. Agroecology and Sustainable Food Systems, 68, 1-22.

MacAuley, L. E., \& Niewolny, K. L. (2016). Situating on-farm apprenticeships within the alternative agrifood movement: Labor and social justice implications. Journal of Agriculture, Food Systems, and Community Development, 6(2), 195-223.

Marx, K. (1986). Capital. Penguin Books. 
Schell, G. (2002). "Farmworker exceptionalism under the law: How the legal system contributes to farmworker poverty and powerlessness.' In: J. Thomson, D. Charles and M. F. Wiggins (eds.), The Human Cost of Food: Farmworkers' Lives, Labor, and Advocacy (pp. 139-166). Austin, TX: University of Texas Press.

Shreck, A., Getz, C., \& Feenstra, G. (2006). Social sustainability, farm labor, and organic agriculture: Findings from an exploratory analysis. Agriculture and Human Values, 23, 439-449.

Rodman, S. O., Barry, C. L., Clayton, M. L., Frattaroli, S., Neff, R. A., \& Rutkow, L. (2016). Agricultural exceptionalism at the state level: Characterization of wage and hour laws for U.S. farmworkers. Journal of Agriculture, Food Systems, and Community Development, 6(2), 89-110.

USDA. (2010, November 1). Limited Resource Farmer and Rancher - Beginning Farmer Program Definition. Retrieved from https://lrftool.sc.egov.usda.gov/BFRP_Definition.aspx.

Weiler, A. M., Otero, G., \& Wittman, H. (2016). Rock Stars and Bad Apples: Moral Economies of Alternative Food Networks and Precarious Farm Work Regimes. Antipode, 48(4), 1140-1162. 